\title{
Article
}

\section{'The Best of Times and the Worst of Times': Reflections on Developing a Prison-Based Business Law and Tax Clinic in the Midst of a Global Pandemic}

Codd, Helen Louise, Blackburn, Lucy Emma, Massey, David lan alexander, Wood, Deborah and Jones, Stephanie Lynne

Available at http://clok.uclan.ac.uk/36774/

Codd, Helen Louise ORCID: 0000-0003-4495-9347, Blackburn, Lucy Emma ORCID: 0000-0001-8045-2872, Massey, David Ian alexander ORCID: 00000002-6853-3845, Wood, Deborah and Jones, Stephanie Lynne (2020) 'The Best of Times and the Worst of Times': Reflections on Developing a PrisonBased Business Law and Tax Clinic in the Midst of a Global Pandemic. International Journal of Clinical Legal Education, 27 (4). pp. 39-61. ISSN 14671069

It is advisable to refer to the publisher's version if you intend to cite from the work. 10.19164/ijcle.v27i4.1053

For more information about UCLan's research in this area go to http://www.uclan.ac.uk/researchgroups/ and search for <name of research Group>.

For information about Research generally at UCLan please go to http://www.uclan.ac.uk/research/

All outputs in CLoK are protected by Intellectual Property Rights law, including Copyright law. Copyright, IPR and Moral Rights for the works on this site are retained by the individual authors and/or other copyright owners. Terms and conditions for use of this material are defined in the policies page. 
Practice Report

‘THE BEST OF TIMES AND THE WORST OF TIMES’: REFLECTIONS ON

DEVELOPING A PRISON-BASED BUSINESS LAW AND TAX CLINIC IN THE

MIDST OF A GLOBAL PANDEMIC

Helen Codd, Lucy Blackburn, David Massey, Deborah Wood E Stephanie Jones ${ }^{1}$

\section{Introduction}

This practice report explores the dynamics, opportunities and challenges of developing an in-prison CLE programme offering advice on business law and tax, against the backdrop of the COVID-19 pandemic and the pre-existing constraints of prison security. This initiative has its roots in two clinical education initiatives at the University of Central Lancashire (UCLAN) - an existing Business Law Clinic based in the School of Justice, and an experimental low-income taxation advice project run by the UCLAN Business School. The interdisciplinary team taking forward this project includes staff with expertise and experience in taxation, CLE, business law, penology, and prison research.

\footnotetext{
${ }^{1}$ Helen Codd, Professor of Law \& Social Justice, School of Justice, UCLAN; Lucy Blackburn, Senior Lecturer in Law, School of Justice, UCLAN; David Massey, Lecturer in Taxation, School of Business, UCLAN ; Deborah Wood, Lecturer in Accounting \& Finance, School of Business, UCLAN ; Stephanie Jones, Senior Lecturer in Law, School of Justice, UCLAN. Email: hlcodd@uclan.ac.uk \& leblackburn@uclan.ac.uk
} 


\section{Clinical Education at UCLAN}

Legal education at UCLAN has a long history of commitment to clinical legal education, and to offering students opportunities to develop 'real life' skills and experience, including the provision of legal advice. In the early years, prior to the mid1990s, this was offered via the Preston Free Legal Information Service, which was based in the Law Department and which employed a part-time legal caseworker to oversee student volunteers along with experienced and professionally qualified academic staff. This in turn led to the creation of a generalist Law Clinic, and more recently a specialist Business Law Clinic, which has developed to include a specialist Franchise Clinic. In addition, UCLAN works alongside a local solicitors' firm to provide a free Immigration Clinic once a month. The Business Law Clinic was established to provide local SMEs and entrepreneurs with guidance relating to matters such as contracts, intellectual property and GDPR. Run by Stephanie Jones and providing real-world experience for UCLAN's students and graduate legal advisers, clients are provided with six months of support which includes written advice and drafting of documentation. Helping small businesses and providing experience for otherwise disadvantaged graduates and students casts a less-traditional lens on social justice but it is certainly a valid one. To date, the clinic has advised over 170 small businesses but the need for this type of help is evidenced by a 2018 report of the Legal Services Boardbased on research over five years where they concluded: 
"we estimate the annual cost of small businesses' legal problems to the UK economy to be roughly $£ 40$ bn. Furthermore, 20\% of businesses reported health impacts on personnel, which extrapolates to a minimum of $1.1 \mathrm{~m}$ individuals, with possible knockon effect for health services." 2

Over $50 \%$ of small businesses try to solve their legal problems completely alone. The legal and regulatory needs of small businesses, start-ups and charities are often overlooked because these organisations are presumed to have money in their budgets that can be used to pay for legal advice, but this becomes unlikely, particularly in an era of difficult trading conditions and rising legal fees. Many law firms offer a 30minute free consultation but that is simply not enough to allow a small business to create a compliant structure where problems can be prevented rather than simply latterly reacted to. The Business Law Clinic was the first business-dedicated clinic of its kind in the North West and helps UCLAN undergraduates and graduates gain otherwise elusive experience of working with commercial clients. The Business Law Clinic attempts to level the playing field for UCLAN graduates and students whose A-level results or social background may prohibit them from acquiring essential work experience in commercial law firms, which recruit mainly from Russell Group universities. Over $88 \%$ of trainee solicitors in commercial law firms are recruited from

\footnotetext{
${ }^{2}$ https://research.legalservicesboard.org.uk/wp-content/media/FINAL-Small-Business-Report-FEB2018.pdf (accessed 16 October 2020).
} 
Russell Group universities ${ }^{3}$ with most of those trainees coming from middle class backgrounds ${ }^{4}$. Almost $70 \%$ of graduate employers see relevant work-experience as an essential part of a graduate job application ${ }^{5}$. In addition, a group of students and staff began delivering will-writing sessions in a local training prison in 2019, and there are clear potential links between will-writing, financial planning and taxation matters.

Within the Business School at UCLAN, the Law and Taxation modules offered have adopted an ephebagogic philosophy (developing students as emerging adults) but, within an accounting curriculum geared to professional exemptions, have struggled to incorporate the exposure to the real-world that this requires. ${ }^{6}$ Business schools fall well behind their law school colleagues in offering clinical opportunities to their students and in providing pro bono services for those in need of them.

An opportunity arose to begin addressing this missing element in students' learning via the creation of a low-income tax clinic. This was a partnership between UCLAN's Business School, Lancaster University Law School and the national charity, TaxAid. The clinic completed its 10-week pilot stage in March 2020 just days before university campuses moved to online delivery and remote working where possible. Although

\footnotetext{
${ }^{3}$ http://www.chambersstudent.co.uk/where-to-start/newsletter/law-firms-preferred-universities accessed 16 October 2020

${ }^{4}$ https://www.gov.uk/government/uploads/system/uploads/attachment data/file/434791/A qualitativ e evaluation of non-educational barriers to the elite professions.pdf accessed 15 October 2020.

${ }^{5}$ https://www.ucas.com/connect/blogs/work-experience-important accessed 15 October 2020.

${ }^{6}$ Lucy Blackburn, 'Ephebagogy and Clinical Legal Education' [2020] 27(2) International Journal of Clinical Legal Education <https://www.northumbriajournals.co.uk/index.php/ijcle/article/view/962> accessed 29 October 2020
} 
short, the pilot was sufficient to demonstrate that there was a demand for tax advice that UCLAN business students could fulfil7.

\section{Prison Research at UCLAN}

Interdisciplinary prison research is a key strength at UCLAN, including demonstrable strong links with local criminal justice agencies and institutions, including prisons, and a strong record of conducting research in prison settings and working with a range of professionals in consultative roles. The cross-faculty Criminal Justice Partnership includes a specific prisons strand and thus students involved in delivering the proposed clinic will be supported by staff with extensive practical experience and a high level of expertise in working in prison settings. ${ }^{8}$

\section{Why set up a Business Law and Tax clinic in a prison?}

There are both pragmatic and theoretical justifications for developing and delivering a prison-based business law and tax clinic. Indeed, tax clinics are offered in prisons by

\footnotetext{
7 Amy Lawton and David Massey, 'Out and About - North West Tax Clinic and pro bono tax advice' [2020] 186(4765) Taxation <https://www.taxation.co.uk/articles/north-west-tax-clinic-and-pro-bonotax-advice> accessed 29 October 2020

Amy Lawton and David Massey, 'Opening our doors' [2020] October 2020 Tax Adviser $<$ https://www.taxadvisermagazine.com/edition/5756> accessed 29 October 2020

${ }^{8}$ For the purposes of this article, the term 'prison' will be used in its broadest sense, as the location of the detention of some of those people who are awaiting trial or sentence, and the location of the detention of those offenders who receive custodial sentences including imprisonment (for adults aged $21+$ ) and young offenders (under 21). This broad definition, therefore, includes establishments which are not technically 'prisons' as they are, for example, 'Young Offender Institutions' for those aged under 21.
} 
a number of US law schools, including Harvard, Fordham and several others. Universities in the UK often deliver programmes within prisons, one of the most wellknown being the range of "Learning Together" programmes which to date have involved over 600 students $^{9}$. Alongside this there are free legal and advice services, some of which utilise volunteers including students. These often focus on prisoner welfare, family contact, family disputes and planning for release, including issues of housing and welfare benefits. At first glance, it may not be apparent that there is an unmet need for prisoners to have access to advice about business law and taxation. However, as a consequence of the publicity for the tax clinic the staff involved were approached (through Twitter) by a social enterprise and asked whether students might also assist prisoners to resolve their tax issues with Her Majesty's Revenue and Customs (HMRC). It became clear that the tax difficulties facing prisoners mirrored those faced by the tax clinic's low-income clients, in particular the challenges of getting up-to-date with outstanding tax returns.

This unmet need is exacerbated by the prison setting. The pilot study had already identified digital and telephonic poverty and exclusion as a difficulty for many of the tax clinic clients. HMRC closed the last of its local Enquiry Centres in 2014, replacing these initially with telephone helplines. More recently HMRC has been moving to the

\footnotetext{
${ }^{9}$ See Natalie Gray, Jennifer Ward and Jenny Fogarty, (2019) ‘Transformative learning through university and prison partnerships: reflections from 'Learning Together' Pedagogical Practice'. Journal of Prison Education and Re-entry, 6 (1). pp. 7-24.
} 
use of online services as the preferred medium for interaction with its customers. This poses particular problems for prisoners, who have limited and controlled access to telephones and very restricted and limited internet access. Whilst it is usually the case that prisoners are denied internet access, there may be occasions where prisoners are given limited access to selected websites via 'locked down' terminals and laptops. There is no automatic sharing of information between HM Prison and Probation Service (HMPPS) and HMRC, and thus HMRC do not know that another arm of Government holds the individual as a prisoner. For prisoners who are self-employed prior to their sentence, a custodial sentence can lead to the cessation of trading, but HMRC will continue to send demands for tax returns and payments to old addresses, unaware that the individual is incarcerated. The minimum penalty for being a year late with a tax return is $£ 1,600$ even if no tax is due. A shock can await a newly released prisoner, once HMRC have a new address to which to send demands which may stretch back years.

Penological research has highlighted many aspects of the challenges faced by prisoners on release. ${ }^{10}$ Prisons offer vocational training in a range of skills, but exprisoners often find that their criminal history is a barrier to employment. The challenges of finding employment are being exacerbated by the impacts of COVID-19, and governmental and public health responses to control the spread of the virus.

\footnotetext{
${ }^{10}$ Eldon Maguire and Peter, Raynor, 'Preparing prisoners for release: current and recurrent challenges' in Pamela Ugwudike, Hannah Graham, Fergus McNeill, Peter Raynor, Faye S. Taxman, Chris Trotter (eds) The Routledge Companion to Rehabilitative Work in Criminal Justice (Routledge, 2020), pp. 520-532.
} 
Although the precise impacts of COVID-19 and the first UK-wide lockdown are as yet unknown, and indeed there may be further local, regional and national lockdowns ${ }^{11}$, it is clear that the UK is in a period of economic recession, and at the time of writing unemployment is rising and many businesses are either ceasing to trade, restructuring including staff redundancies, or ceasing recruitment to new posts. This makes accessing employment even more challenging for people leaving prison. With this in mind, self-employment may offer the only feasible route to non-criminal economic engagement, and indeed the vocational skills opportunities offered in men's prisons include a range of skills which would lend themselves to self-employment after release, such as skills as car mechanics, and in building and related trades. Indeed, the desire to become self-employed or set up a business after release was highlighted by the Forward Trust in August 2020, in response to data released in July that showed $88 \%$ of offenders released from custody between March and June who were available to work were unemployed. ${ }^{12}$

That said, even if the desire is there, ex-prisoners may not have the basic awareness or knowledge of relevant legal and taxation requirements to feel confident in going ahead to 'go it alone' or set up small businesses after release. Grosholz et al. highlight that the current literature indicates there is little research on the effect of entrepreneurial training on the behaviour and identity of those who have been

\footnotetext{
${ }^{11}$ This article was written before the second national lock-down in England in November 2020

${ }^{12}$ Community Performance Quarterly release to March 2020, Ministry of Justice, July 2020. See www.forwardtrust.co.uk accessed 1 September 2020.
} 
incarcerated. ${ }^{13}$ This project enables students to be involved in a project which could have real impact in an emerging field of entrepreneurship research, as well as on CLE research. More broadly, the research on desistance from offending, community reintegration and resettlement after release, stresses the significance of strong family and community relationships in preventing reoffending in the future. This project could have long term individual and societal benefits in helping convicted offenders move on from prison to become economically independent.

It is important to set out from the outset that although this in-prison clinic is being developed for delivery in a men's prison, in the future we would like to explore the needs of women prisoners in women's prisons. Research with women prisoners has demonstrated long-running concerns about employment after release, especially as women ex-prisoners have a high unemployment rate, and existing prison educational and vocational programmes often focus on skills which would translate well to selfemployment and the creation of small businesses, as exemplified in the hair and beauty training salon at HMP Styal. ${ }^{14}$

\footnotetext{
${ }^{13}$ Jessica M. Grosholz, Jean D. Kabongo, Michael H. Morris, Ashley Wichern (2020) ‘Entrepreneurship Education in the Transformation of Incarcerated Individuals: A Review of the Literature and Future Research Directions', International Journal of Offender Therapy and Comparative Criminology 64(15) pp. 1551-1570.

${ }^{14}$ Prison Reform Trust \& Working Chance (2020) Improving Employment Opportunities for Women with Criminal Convictions, London (Prison Reform Trust 2020).
} 


\section{CLE as Social Justice}

From a more theoretical perspective, although CLE was being discussed in the $1930 \mathrm{~s}^{15}$, the CLE movement began in earnest in post-1968 Europe and was grounded in social reform. At that time, basic legal services were available to just a few and revealed the major inequality of access to justice for the vast majority. ${ }^{16}$ The provision of free legal advice to those in need is one of the central themes of CLE, as one of the main ideological aims of CLE is the commitment to educating lawyers for social justice. ${ }^{17}$ Pro bono legal advice has been around in many guises for many years. A law clinic, in whatever format or guise, will introduce students to the local community. With CLE projects, students are placed in situations outside of their perceived comfort zone and are given the opportunity to interact and empathise with a diverse range of people from a diverse range of backgrounds. ${ }^{18}$

CLE is often associated with the provision of legal aid to the poor, marginalised and disadvantaged in society. ${ }^{19}$ However, in the purest form of the pro bono clinic, its

\footnotetext{
${ }^{15}$ Jerome Frank 'Why not a Clinical Lawyer School? [1933] 81, University of Pennsylvania Law Review 907, 915

${ }^{16}$ Jeff Giddings, Roger Burridge, Shelly AM Gavigan and Catherine F Klein, 'The First Wave of Modern Clinical Legal Education: The United States, Britain, Canada and Australia' in Frank S Bloch (ed), The Global Clinical Movement: Educating Lawyers for Social Justice (Oxford University Press, 2011), 3 ${ }^{17}$ This is the central theme of Bloch in Frank S. Bloch (ed), The Global Clinical Movement: Educating Lawyers for Social Justice (Oxford University Press, 2011).

${ }^{18}$ Lucy Blackburn, 'Ephebagogy and Clinical Legal Education', Int'1 J Clinical Legal Educ (2020), 135154,152

${ }^{19}$ Frank S. Bloch \& Mary Anne Noone 'Legal Aid Origins of Clinical Legal Education' in Frank S Bloch (ed), The Global Clinical Movement: Educating Lawyers for Social Justice (Oxford University Press, 2011) 153
} 
principal purpose is to deliver legal services to those who could not otherwise afford them, to right the wrongs that would otherwise go without redress. It may raise students' consciousness of inequality and injustice and provide the academic with the means of salvaging his conscience. ${ }^{20}$ At the heart of any CLE programme, whether it be a credit bearing module or extracurricular volunteering, running alongside the deep learning experience, will be the promotion of access to justice. In the 1960's the anti-poverty and civil rights campaigns in the United States saw law clinics develop, helped by the backing of many charities. ${ }^{21}$ In the UK, many law clinics have helped to 'plug the gap' in legal services which resulted in the cuts to Legal Aid following the introduction of the Legal Aid, Sentencing and Punishment of Offenders Act 2012 (LASPO). ${ }^{22}$

Globally, a number of projects are assisting the social justice/access to justice agenda within university law clinics. ${ }^{23}$ These can range from Refugee Law Clinics in the Central European and Baltic States, ${ }^{24}$ Women's law clinics in Nigeria, ${ }^{25}$ to the

\footnotetext{
${ }^{20}$ Max Weaver, 'Clinical Legal Education - Competing Perspectives' (1983) 17 Law Teacher 1, 4

${ }^{21}$ Hugh Brayne, Nigel Duncan \& Richard Grimes, Clinical Legal Education: Active Learning in your Law School (Blackstone Press Limited) 1998, 11

${ }^{22}$ There are fascinating arguments about whether law clinics should be addressing this gap in the legal services market, but these are not relevant to this brief report.

${ }^{23}$ 'Social justice through access to justice is aimed at educating the neglected members of a community whiles addressing their legal problems. Ibijoke Patricia Byron, 'Between Social Justice and Clinical Legal Education: A Case Study of the Women's Law Clinic, Faculty of Law, University of Ibadan, Nigeria', Int'1 J. Clinical Legal Educ 20 at 567

${ }^{24}$ Stephan Anagnost, 'Promoting Refugee Law as a Means of Challenging the Status Quo at University Level Education in Europe: The Role of the Refugee Law Clinic' Int'1 J. Clinical Legal Educ, [2014] 38

${ }^{25}$ Byron above
} 
internationally renowned Innocence Project. ${ }^{26}$ Examples in the UK include The Community Legal Outreach Collaboration Keele (CLOCK), which is an 'innovative multi-agency initiative driven by legal academics, in collaboration with the legal profession, court and charitable sector ${ }^{27}$ and also the work with the Third Sector that has been conducted by the University of Cardiff law clinics. ${ }^{28}$ Students who may have just left home for the first time are put into direct contact with issues that may never have affected their community. ${ }^{29}$ Anagnost argues that CLE "encourages good humanitarian attitudes plus the combination of theory and practice". ${ }^{30}$

Even though she writes in the context of CLE in Nigeria, Byron's writings on the link between social justice and legal education are relevant to domestic CLE. Within Byron's writings she refers to Voyvodic and Medcalf and their assertion that when a social justice mission is established within a guided practice setting, the students are

\footnotetext{
26 'The Innocence Project, founded in 1992 exonerates wrongly convicted persons through DNA testing and works to reform the criminal justice system to prevent future injustice.' Whilst it is not wholly a clinical law programme, of the 56 US based organisations within the network 26 are located within Universities. www.innocenceproject.org

${ }^{27}$ For more information see Jane Krishnadas, 'CLOCK 'The Community Legal Companion; as an Agent of Change: A Transformative Methodology" in Re-imagining Clinical Legal Education. Linden Thomas, Steven Vaughan, Bharat Malkani and Theresa Lynch (eds) (Hart Publishing, 2018)

${ }^{28}$ See Jason Tucker, 'Third- Sector- Funded Clinical Legal Education in the United Kingdom: A Reflection and Proposal for Future Partnerships' in in Re-imagining Clinical Legal Education. Linden Thomas, Steven Vaughan, Bharat Malkani and Theresa Lynch (eds) (Hart Publishing, 2018)

${ }^{29}$ Seear et al argue that CLE' provides a unique opportunity for students to deeply engage with emotions, in part because emotions are experienced as a regular feature of clinics': Kate Seear, Lisa Bliss, Paula Galowitz \& Catherine F. Klein ' Exploring the role of emotions in clinical legal education: inquiry and results from an international workshop for legal educators'. The Law Teacher, 53: 4 [2019], 487-499, 489

${ }^{30}$ Stephan Anagnost, 'Promoting Refugee Law as a Means of Challenging the Status Quo at University Level Education in Europe: The Role of the Refugee Law Clinic', Int'1 J. Clinical Legal Educ, 38 [2002) 41
} 
provided with a "key linkage" between their legal education and also the long-term engagement with the advancement of social justice. ${ }^{31}$

There are therefore strong social justice arguments for CLE projects to engage with prisons and prisoners. In England \& Wales the prison population is the highest in Europe, and, as in many countries, particularly the US, there has been a shift over the last two decades towards increasing use of imprisonment and the imposition of longer sentences than previously, which exceed sentences for comparable offences in many other jurisdictions. At the moment, the biggest prison-building programme in England and Wales since the $19^{\text {th }}$ century is underway, and this inexorable "prison boom' shows no signs of abating despite governmental stated aspirations to limit the use of short prison sentences. That said, prisons and prisoners are often invisible in our society and among our students unless and until imprisonment is experienced within their own family, kin and friendship groups, or until they encounter prison issues as part of penology and criminal justice modules. ${ }^{32}$ Some students, of course, are former prisoners themselves, or have long experience of imprisonment affecting family members, but for many this kind of clinic activity would offer them their first opportunity to work within a closed setting, and could challenge their pre-existing views of prisons, prisoners and ex-prisoners. A growing body of work acknowledges

\footnotetext{
${ }^{31}$ Byron, p.564

32 Helen Codd, In the Shadow of Prison: Families, Imprisonment and Criminal Justice, (Willan, 2008).
} 
the importance of empathy in ethical leadership and recognises the importance of presenting students with opportunities to see life through the eyes of others.

\section{Developing the Business Law and Tax Clinic during the pandemic}

Even without the COVID pandemic, setting up an in-prison clinic for students poses a wide and varied range of challenges. Prisons vary widely not only in their security categorisations, but also in terms of management attitudes to interaction with students, and also the constraints of staffing available to oversee such interactions and ensure safety and security for all involved. UCLAN is exceptionally well-situated for prison work. In addition the prisons in the North West range from HMP Kirkham and HMP Thorn Cross (which are Category D Open prisons) to busy and overcrowded city-centre local prisons (HMP Preston and HMP Manchester) and prisons for those serving longer sentences including HMP Garth and HMP Wymott, which are on adjoining sites. This is helpful in terms of taking the project forward, because although some of these prisons are in semi-rural areas, they are all relatively accessible in comparison with prisons in other parts of the UK, such as HMP Haverigg in Cumbria and HMP Dartmoor. This project also benefits from existing working relationships between staff on the team and prisons, and informal discussions indicated that the initiative would be likely to be welcomed by a number of prisons, so approval in principle was not regarded as problematic. 


\section{The Impact of the Pandemic}

However, particular questions and issues have arisen in the context of the impact of COVID-19 on prison regimes, including access and visits, which were halted as a consequence of the lockdown and are now very limited ${ }^{33}$. COVID-focused scrutiny inspections of establishments, the reports of which are published by HM Inspectorate of Prisons, highlight very limited and restricted opportunities for contact not only between prisoners but also between prisoners and their friends, families and outside organisations. It is also important to recognise that immediately prior to the development of the pandemic in the UK early in 2020, there were emerging limitations on face-to-face contact between university students and prisoners, following a review of such contacts which followed the terror attack at a Learning Together event at Fishmonger's Hall in November 2019. As in many aspects of university activities, the obvious response would be to deliver a fully online programme for all participants. The precise nuances of this mode of operation are heavily regulated, however, by restricted prison internet access and security rules, combined with prison IT infrastructural issues. Discussions are underway with the staff of the social enterprise, which already has staff based in prisons, and thus even if students are not approved for face-to-face contact with prisoners via the internet, with appropriate clearance

\footnotetext{
${ }^{33}$ Kay, Chris (2020): Covid-19 in custody: Responding to pandemics in prisons in England and Wales. British Journal of Community Justice,. https://hdl.handle.net/2134/12624596.v1 accessed 14 September 2020.
} 
students may be able to assist in providing advice via the social enterprise staff as intermediaries.

\section{Practical Challenges}

In advance of launching the clinic, students within the Business School have been tasked with addressing the challenges that both the COVID-19 restrictions and the general digital restrictions have posed for the social enterprise and the prisoners and ex-prisoners that they work with. For Level 5 coursework they are currently exploring, for example:

- how to translate online materials into paper formats - where there is no option to click through a link for further information;

- how to use language and images that are most effective at communicating to those without strong literacy and numeracy skills;

- ways either to work with HMRC's online systems or to challenge the authorities to change them.

It was planned initially that the clinic would operate in pilot form from January to May 2021, although this has been delayed due to the pandemic. A virtual clinic model has been devised which will depend on close collaboration between the social enterprise organisation working in the prison and student volunteers. The Business Law Clinic had to move swiftly to virtual meetings in March 2020 and thus provided 


\section{Practice Report}

an inadvertent pilot for some aspects of the prison-centred advice clinic. The social enterprise will identify business start-up project work for their clients which will be completed by small interdisciplinary student teams. Students will be supported by academics across the Business School, School of Justice and Criminal Justice Partnership. Thus, even if the face-to-face client experience may be missing for some time yet, there are still many opportunities to give students the chance to work on real life problems and to begin thinking in a client-focussed way. This model also gives the students the opportunity to work with the not-for-profit sector, something that is different to the usual commercial opportunities that students are offered. The project will allow the learner to explore unfamiliar settings and interactions. From a user point of view, the multidisciplinary approach, including law-focused, taxationfocused and business-focused students means that the offering is an enhanced, multiperspective and holistic wraparound programme which offers more joined-up support to people wanting to establish their own businesses after release than a singledisciplinary project could provide. It is envisaged that the clinic will continue to offer 'through the gate' support after release as well as pre-release, so as to enable new entrepreneurs and business owners to develop the appropriate skills, awareness, experience and knowledge to make a success of their business after release.

Online technology, including websites and apps, is attractive for the delivery of clinic programmes generally for a number of reasons, including convenience. That said, internet access in prisons has historically been very limited, as has (legal) possession 


\section{Practice Report}

of mobile phones. There has been a scheme enabling family members to send emails to prisoners for some years, but this would only be useful in limited aspects of providing advice, such as in relation to sending documents. Similarly, prisoners themselves may need support in accessing and using online technologies, as especially if they have served long sentences, they may not have any relevant skills in using mobile or IT technologies. In many ways, it would seem easier to run an in-prison clinic face-to-face rather than try to negotiate the manifold challenges of enabling prisoners to access the internet, although broadening prisoners' internet access is a matter of ongoing policy debate. However, the pandemic prompted attempts at radical change in many establishments, including the distribution of 'locked down' mobile phones to prisoners, allowing access only to certain approved telephone numbers, and the introduction of internet-based Purple Visits for family contact.

The Purple Visits secure video calling platform offers what their provider refers to on their website as "a feature-rich video calling solution specially designed for use within secure establishments'" 34 The platform offers military-grade encryption and claims to offer a reliable, simple-to-use and cost-effective means of allowing prisoners and their families to remain in contact. As a consequence of the pandemic, most prisons in the UK have introduced Purple Visits, which are available to prisoners aged $18+$, and offer a 30-minute visit once a month. The exact process for setting up the visit varies from prison to prison, some allowing a choice of pre-booked visit times.

\footnotetext{
${ }^{34}$ See www.purplevisits.com
} 
The experience of introducing this platform for visits has prompted mixed reactions. Many prisons are viewing the process as a positive development, especially in facilitating contact between prisoners and family members who would not able to travel to the prison for a face-to-face visit in non-pandemic times. However, emerging anecdotal evidence reveals that the experiences of users themselves to date have been more mixed. ${ }^{35}$ These video calls rely on those outside the prison having access to hardware on which they can install the app, and also the ability, skills and capacity to use it. The early months of usage have seen ongoing technical problems, including calls disconnecting and cutting out frequently, much to the frustration of the prisoners and family members themselves.

This platform could, in theory, offer a viable way forward for offering clinic appointments, subject to improvements in the infrastructure and the approval of prison management. However, a key issue with Purple Visits is one of cost. While these 'visits' are being offered free of charge at present as an alternative to face-to-face visits which may not be permitted during the pandemic, HMPPS was already exploring the potential for video-calling prior to 2020, when there were discussions around a proposed charge for such 'visits' of $£ 8-10$ per session. When we discuss clinical education clinics, these are relatively low-cost, as students are volunteers and whilst there may be transport and consumables costs, these are not likely to be high.

\footnotetext{
${ }^{35}$ Personal communications, 'Lessons from the Lockdown' online seminar, University of South Wales, $17^{\text {th }}$ September 2020. Recording is available at https://criminology.research.southwales.ac.uk/news/2020/video-lessons-lockdown-prisoner-andfamily-connections-future/
} 


\section{Practice Report}

However, Purple Visits as a means of delivering the clinic programme will need to be funded, and prisoners and their families may not have the financial resources to support this. Going forward, we are exploring the potential for professional sponsorship of these sessions, perhaps via partnerships with local firms and businesses, and also looking for funding from several sources, including those offering financial support for ex-prisoners and those leaving custody. The costs may not be high in relative terms, but as Purple Visits are not free of charge, if we seek to run the prison clinic via this platform then even if this is feasible, the calls will need to be funded. A related issue is one of oversight and staffing within the prison. For example, prisons have experienced unprecedented cuts in staffing numbers in recent years, and in many institutions, this lack of staff has led to lower levels of access to educational and recreational opportunities as there are no staff available to supervise prisoners' movement. Ironically, the COVID situation means that over the next months and year, as the consequences of both the COVID epidemic and BREXIT emerge, more and more prisoners and ex-prisoners may need tax and business advice, but the combination of pre-COVID funding cuts and the challenges of coping with COVID itself in a closed setting may mean that prison management and staff have to put all their energy and resources into the core business of keeping prisons and prisoners safe and well, with little flexibility as to the introduction of new programmes. That said, one of the advantages of this programme, if we are able to negotiate a platform and process for delivering it in-prison, is that it will offer students 
opportunities to gain clinical experience at a time when face-to-face working in many situations is impossible, especially in areas experiencing high numbers of virus cases.

\section{Conclusion}

At the time of writing the clinic is very much 'work in progress', subject to unpredictable changes in government guidance, changes in prison management, priorities and regimes, and also subject to changes in decision making at the university institutional level. The rationale for going forward and delivering a clinic remains clear, and there are clear potential positive impacts for students, prisoners and exprisoners. The precise shape, structure and delivery method is still undergoing development. Evidence-based evaluation of the impacts and outcomes of the programme will be integral to the design and delivery, and thus in due course we look forward to being able to look back and reflect on the final project. The need is still there, and our commitment is still there, but if COVID-19 has taught us all only one lesson, it is that change is constant and that, in clinical education like many things, a flexible and change-responsive approach is essential.

\section{References}

Anagnost, S. 'Promoting Refugee Law as a Means of Challenging the Status Quo at University Level Education in Europe: The Role of the Refugee Law Clinic' Int'l J. Clinical Legal Educ, 38 (2002) 41 
Blackburn, L. 'Ephebagogy and Clinical Legal Education' [2020] 27(2) International $\begin{array}{llll}\text { Journal of Clinical } & \text { Legal } & \text { Education }\end{array}$ <https://www.northumbriajournals.co.uk/index.php/ijcle/article/view/962> accessed 29 October 2020

Bloch, F.S. \& Noone, M.A. 'Legal Aid Origins of Clinical Legal Education' in Frank S Bloch (ed), The Global Clinical Movement: Educating Lawyers for Social Justice (Oxford University Press, 2011) 153

Brayne,H. Duncan, N. \& Grimes, R. Clinical Legal Education: Active Learning in your Law School (Blackstone Press Limited, 1998), 11

Byron, I.P. 'Between Social Justice and Clinical Legal Education: A Case Study of the Women's Law Clinic, Faculty of Law, University of Ibadan, Nigeria' Int'1 J. Clinical Legal Educ 20 at 567

Codd, H. 'In the Shadow of Prison: Families, Imprisonment and Criminal Justice' (Willan, 2008).

Community Performance Quarterly Release to March 2020, (Ministry of Justice, July 2020): .www.forwardtrust.co.uk accessed 1 September 2020.

Frank, J. 'Why not a Clinical Lawyer School? [1933] 81, University of Pennsylvania Law Review 907, 915

Giddings, J., Burridge, R., Gavigan, S. and Klein, C. 'The First Wave of Modern Clinical Legal Education: The United States, Britain, Canada and Australia' in Frank S Bloch (ed), The Global Clinical Movement: Educating Lawyers for Social Justice (Oxford University Press, 2011), 3

Gray, N. Ward, J. and Fogarty,J. [2019] 'Transformative learning through university and prison partnerships: reflections from 'Learning Together' Pedagogical Practice'. Journal of Prison Education and Re-entry, 6 (1). pp. 7-24.

Grosholz,J., Kabongo,J., Morris, M.,\& Wichern, A. [2020] Entrepreneurship Education in the Transformation of Incarcerated Individuals: A Review of the Literature and Future Research Directions, International Journal of Offender Therapy and Comparative Criminology 64(15) pp. 1551-1570.

Kay, C. (2020): Covid-19 in custody: Responding to pandemics in prisons in England and Wales. British Journal of Community Justice [2020] https://hdl.handle.net/2134/12624596.v1 accessed 14 September 2020. 
Krishnadas, J. (2018) 'CLOCK: 'The Community Legal Companion' as an Agent of Change: A Transformative Methodology' in Re-imagining Clinical Legal Education. Thomas, L., Vaughan, S., Malkani, B. and Lynch, T. (eds) Hart Publishing 2018

Lawton, A, and Massey, D., 'Out and About - North West Tax Clinic and pro bono tax advice' [2020a] 186(4765) Taxation <https://www.taxation.co.uk/articles/northwest-tax-clinic-and-pro-bono-tax-advice> accessed 29 October 2020

Lawton, A. and Massey,D. 'Opening our doors' [2020b] October 2020 Tax Adviser <https://www.taxadvisermagazine.com/edition/5756> accessed 29 October 2020

Maguire, E. and Raynor, P. 'Preparing prisoners for release: current and recurrent challenges' in Pamela Ugwudike, Hannah Graham, Fergus McNeill, Peter Raynor, Faye S. Taxman, Chris Trotter (eds) The Routledge Companion to Rehabilitative Work in Criminal Justice (Routledge, 2020), pp. 520-532.

Prison Reform Trust \& Working Chance, Improving Employment Opportunities for Women with Criminal Convictions, (Prison Reform Trust, 2020_

Seear,K. Bliss, L., Galowitz, P. \& Klein, C. ' Exploring the role of emotions in clinical legal education: inquiry and results from an international workshop for legal educators. The Law Teacher, 53: 4 (2019), 487-499, 489

Tucker, J. (2018) Third- Sector-Funded Clinical Legal Education in the United Kingdom: A Reflection and Proposal for Future Partnerships in Re-imagining Clinical Legal Education. Thomas, L., Vaughan, S., Malkani, B. and Lynch, T. (eds) Hart Publishing.

Weaver,M. 'Clinical Legal Education - Competing Perspectives' (1983) 17 Law Teacher 1,4 